\title{
Factors Influencing Saudis Investors' Attitude to Invest in Islamic Mutual Funds
}

\author{
Saiyer Aljaed \\ School of Business ,Taif University, Saudi Arabia \\ E-mail: sayer-151@hotmail.com \\ Dr. Maizaitulaidawati MdHusin \\ Azman Hashim International Business School, UTM University, Malaysia \\ Prof. Wan Khairuzzaman Wan Ismail \\ Azman Hashim International Business School, UTM University, Malaysia \\ Samiah Aljaud \\ School of Business , Taif University, Saudi Arabia
}

\begin{abstract}
Islamic financial services are currently among the internationally growing trends in the world financial market. An attempt is made in this study to investigate factors that influence Saudi investors' attitudes towards Islamic mutual fund investments. Three factors have been identified by the study namely, religious obligation, awareness, and the social media. Furthermore, a quantitative research design is adopted in this study for data collection and analysis. A total of 166 questionnaires were distributed to investors of five leading mutual funds firms in Saudi Arabia which include Al-Rajhi Capital, Al-Bilad Capital, Al-Inma Investment, Samba Capital and National Commercial Bank (NCB) Capital. Data elicited from the respondents based on a 5-point Likert scale are subjected to multivariate data analysis using the SmartPLS software. The study found that the higher the investors' sense of religious obligation the higher their attitudes towards investing in IMF. Likewise, both awareness and social media significantly influence the investors' attitudes towards Islamic mutual funds. The findings are likely to have some profound academic and practical implications.
\end{abstract}

Keywords: Islamic Mutual Funds, Mutual Funds, Islamic Financial Services, Saudi Arabia

DOI: $10.7176 /$ RJFA/10-8-03

Publication date: April $30^{\text {th }} 2019$

\section{Introduction}

Islamic financial services are currently among the internationally growing trends in the world financial market (Mansor and Bhatti, 2011). Being the center of Islamic faith, the Kingdom of Saudi Arabia is no doubt among the leading countries in Islamic financial services (Abedifar, et al., 2015). Among the Islamic financial services offered in Saudi Arabia is Islamic mutual funds which is considered a potential diamond mine not for Muslims only but for people of all walks of life in the global economic sphere (SAIFR, 2015). However, in spite of the immense potential of this investment market, there is a dearth of empirical studies on the topic in stark contrast to the numerous studies that focus on conventional mutual funds. Although the conventional mutual fund precede its Islamic counterpart by decades, this may not be the only reason for the limited patronage in the latter. It is very significant to understand the factors that influence people's attitudes towards investments in Islamic mutual funds, particularly in places like Saudi Arabia where the entire population of the Kingdom adheres to the Islamic faith.

Thus far, there are quite a few studies that investigated some aspects of Islamic mutual funds. These studies mainly focus on their performance and risk/return features (Abedifar, et al., 2015; Barakat 2011; Dewri, et al., 2016; Ashraf 2013). Interestingly, however, these studies also found that Islamic funds generally outperform their counterpart conventional ones. In spite of their fruitful findings these studies have not given attention to the factors that may have significant influence on the investors' decisions making in Islamic mutual fund industry, especially in Saudi Arabia. One notable study that investigated factors affecting attitude towards Islamic mutual funds is Barakat et al., (2011) in which they identified the lack of awareness and poor attractiveness as basically impacting the efficiency of mutual funds' performance in the financial service industry, particularly in Saudi market.

Based on the findings of Barakat et al. (2011), an attempt is made in this study to investigate the role of religious obligation, awareness and social media in making Islamic mutual funds attractive to investors in Saudi Arabia. Being an Islamic country, religious obligation is the basic factor that guide the 'do and don't' in the country. The awareness of the investors regarding the existence of the Islamic mutual funds is also very crucial as pointed out by prior studies (Chalmers and Reuter 2010; Barakatet al., 2011). Similarly, the role of the social media in enhancing the operational efficiency of the marketing of ideas, products, innovations etc. due to the evolution of information and communication technology globally has been documented (Marsh 2014). 


\section{Theoretical Framework \\ Religious Obligation (RO)}

The terms "religious obligation" and "religiosity", even though are conceptually different are nonetheless often used interchangeably to mean the same thing (Hill and Pargament, 2003). The concept of religiosity has a considerable diversity behind it such that it constantly poses a challenge to researchers in the social sciences to agree on a universal definition. In fact, the complexity of this concept, apart from its inherent meaning, has made it difficult for researchers to study consumer attitudes and purchase intentions. Past studies have also failed to agree on whether religiosity is unidimensional or multidimensional, as well as on the determinants and tools to measure them.

Religious obligation can be defined from two perspectives, namely, theoretical and operational. According to Amin et al (2011), the theoretical definition accentuates on how religious obligation and inclination shape a person's preferences, disposition, perception, activities and choices. On the other hand, the operational part refers to the Sharia rules prohibiting Muslim investors from dealing with any Riba-based investment. These rules guide and encourage investors' attitudes and decisions, respectively, as they invest in Islamic Mutual funds while conforming to the principles of their religious.

Further, studies have revealed that religious obligation affects the day to day behavioral activities of individual. (e.g., Essoo et al., 2004; Al-Hyari et al., 2012; Souiden at et 2015; Al Serhan, 2016; Erol and El-Bdour, 1989; Hirschman, 1983; Wiebe and Fleck, 1980; and Erol et al., 1990). For instance, Hirschman (1983) noted the implication of group identity by stating that a person's rationale for behaving in a particular way or showing preferences for certain activities may be a reflection of the ideology of the faith he professes or the religion he practices. In the same vein, it is likely that people considered to have high level of religiosity may also display a high sense of societal values, self-control and personal discipline in their both their overt and covert conducts including their consumption behavior (Wiebe and Fleck 1980). The authors conclude that religious obligation is one of the primary determinants of the decision making processes of an individual. Against the fact that Islamic obligations are fundamental considerations that affect the daily activities among the Saudis, it is expected that this would affect the investment in Islamic mutual fund in the country. Moreover, it has been shown that religious consideration and then profitability are the two major determinants of attitudes of Islamic bank customers (Metawa and Almossawi, 1998).

By contrast, a Malaysia study by Ahmad and Haron (2002) examined the business attitudes to Islamic banking products and services among 45 corporate clients. The study revealed the corporate consumers gave economic reasons priority over religious factors. Also, the major finding of the study of Souiden et al., (2015) is that religious factors directly influence customers' attitudes' towards and intentions to patronize Islamic banks in Tunisia. Similarly, Al Serhan (2016) empirically explored the role of religion on boycotting and the subsequent brand loyalty behavior. The study confirmed that religiously motivated boycotts exerts substantial and long-term damaging effects on business firms especially reflected in the impairment of their customers' loyalty and retention. The study shows that religious denominations have a significant impact on both boycotting and loyalty behavior

\section{Awareness :}

According to Kotler et al. (2004), awareness means to show or possess knowledge and realization of a particular fact or situation. For the banking industry to remain ever competitive and prosperous, it is germane to explore and understand awareness. Awareness as a concept has been variously defined. It is described as exploring what degree of knowledge the customers know about products and services, and how much information about these they lack (Koltler et al., 2004). Awareness also means an individual's association with a specific product as a means to solving a particular problem (Walter, 1989). In other words, it simply means knowledge of products that are offered (Aminuddin, 1999). Sharon (1999) has averred that there is the need to enhance bank customers' awareness given that the banking sector, in a bid to ensure competition, offers an array of products with a lot of alternatives.

Awareness encompasses making the customers familiar with products and services through promotions, advertisements and several other marketing strategies to publicize brands, special features, benefits, incentives, etc. (Shimp, 1997). Thus, consumer awareness is created for consumers via both words of mouth and the media (Asseal, 1995).

Education is noted as one of the impetuses that enhance the level of awareness in the society. It promotes informed decision among the individual on daily basis, especially as it concerns the financial and investments decisions (Bernheim, et. al 2001). These authors advocated that one way to improve the quality of financial decisions is to invest in educational programs that target financial literacy, hence the awareness. They opined that education enhances individual decision making toward decision concerning defined contribution retirement plan.

In addition, studies have considered comparative awareness of investor between conventional and Islamic instruments (Bley and Kuehn, 2004; Rammal and Zurbruegg, 2007). Hamid and Nordin (2001) examine the difference level of awareness among bank customers in conventional and Islamic mutual funds in Malaysia. The study revealed that there is no significant difference among the customers regarding awareness about both Islamic 
and conventional banking products and services. In addition, Bley and Kuehn's (2004) considered the awareness about financial operations of conventional and Islamic banks among United Emirates' students of business. The authors concluded that awareness concerning Islamic financial products seems higher among the Muslim students compared to their awareness about conventional financial instruments. Further, Rammal and Zurbruegg (2007) administered survey questionnaire on 300 Muslims in Australia to assess their awareness of Islamic banking products and services. The authors found that most respondents are willing to patronize Islamic financial products and services compared to the conventional alternatives.

\section{Social Media:}

The media have encountered significant changes for over a decade (Mangold and Faulds 2009). According to the latest statistics, people who access the internet have exceeded 1.8 billion, comprising about $45.6 \%$ of the total population in Asia stretched across 35 countries and regions (Internet World Stats, 2016). Hence, online consumer behavior should be understood by communication managers given the growing number of social media and internet users worldwide.

The Saudi Communication and Information Technology Commission Report released at the end of Q2 2016 provided specific statistics for the telecom and information technology sector. According to that report, the Kingdom's internet users have rapidly increased, reaching approximately 22.4 million at the end of Q2 2016 with $70.4 \%$ population penetration. Owing to the high usage of social networking applications, broadband and internet service demands have also increased. The significant increase in demand for internet services is expected to continue because of increased internet content, available high-speed fiber-optic networks, and the spread of handheld smart devices that feature highly convenient applications.

According to Mangold and Fauld (2009), consumers are increasingly using social media sites for information, instead of conventional media, such as radio, magazines, and television. Social media has thus transformed conventional communication as it facilitates two-way, multi-dimensional, peer-to-peer communication (Berthonet al., 2008). Consumers interact with one another through social media platforms and rather than source brand communication solely from companies (Li and Bernoff, 2011). Hence, we can say that conventional marketing communication has been changed by the social web.

Advancements in media communication and media technologies have become indispensable in the global business world (Adeyemi et al., 2013). Moreover, business entities throughout the world constantly gather highly accurate information about the global economy and make international investment decisions.

The means and preference of gathering and exchanging information about products and services among consumers have changed dramatically in the past decade. Customers are provided with wide options to acquire and compare information on products and services because of the upsurge of new media. "The digital innovations of the last decade made it effortless, indeed second nature, for audiences to talk back and talk to each other" (Deighton and Kornfeld 2009, p. 4).

New business models are created with the rise of new media, thereby allowing to reach out and communicate with customers as well as measure their browsing, communication, or purchase-related behaviors. New media forms are thus very valuable to a lot of stakeholders including but not limited to marketing strategists, and customer relationship management, which uses information on individual customers to create customized marketing activities.

However, practitioners must first obtain a comprehensive understanding of why customers are attracted to new media and how new forms of media influence consumer behavior before taking the opportunities offered by such new platforms. Such an understanding also helps them avoid risks. Moreover, novel marketing strategies must be created corresponding to the features of new media and their effects on consumers.

Advertising establishes the backbone of brand relationships. Thus, marketers must learn how new multimedia content influences the conventional media consumption. Waldfogel (2007) suggested that consumption of YouTube and other related streaming sites increases the time spent on network websites and reduces TV viewing. Hence, customers' willingness to spend in new media settings must also be understood, even though studies have suggested that the effectiveness of ads online and offline are the same (e.g., Gallagher et al., 2001).

Advertising is described by Armstrong and Kotler (2004) as a non-personal presentation and promotion of goods, services or ideas paid by a known patron. Conventional advertisements through conventional media, such as through radio, television, billboards, and newspaper, are somewhat limited in terms of high cost, limited reach, and one-way interaction. Fortunately, the gradual transition of advertising from conventional media forms to online channels has allowed marketers to overcome the weaknesses and limitations of conventional media (Mulhern, 2009).

Customers' attitudes toward advertising affect how they perceive an ad, which then influences purchasing intentions (Mitchell and Olson, 1981). Consumers' behavioral responses, such as evading online advertising, are caused by their negative perceptions of advertising (Li et al., 2002), which can be attributed to the perceived invasive nature of online ads (Li et al., 2002). According to Zeng et al. (2009) a recipient who finds an online 
advertisement relevant cultivates a positive outlook and reaction toward it. Using both US and China consumer samples, Wang and Sun (2010) explained that there exists a relationship between consumers' perception of online advertising and persuasion. In addition to that, Chu et al. (2013), investigated young consumers' perceptions of social media advertising and their reactions. The authors found that brand consciousness exerts significant influence on users' attitudes toward social media advertising, which in turn, also influences their behavioral disposition. Therefore, consumers' attitude toward social media advertising has a significant relationship with their behavioral responses.

Marsh (2014) stated that consumers are concerned with the integrity of online advertisements, and thus, they are more likely to trust advertisements that appear on reliable websites. The author concluded that the majority of consumers visit dependable news sites to access reliable social media content, and that a critical source of the "media industry's unique value propositions" is a reputation for trust. Clinton et al (2008) reported on the importance of advertising endorsers' credibility in obtaining favorable responses from customers. That is, consumers trust and display favorable attitudes toward a reputable company's social media advertising. Therefore, the relationship between consumers' behavioral responses and their perceptions of social media advertising is mediated by corporate reputation. Another study offered a similar finding, noting that consumers' attitude concerning social media advertising impacts significantly on their behavioral responses (Boateng and Okoe, 2015).

\section{Conceptual framework:}

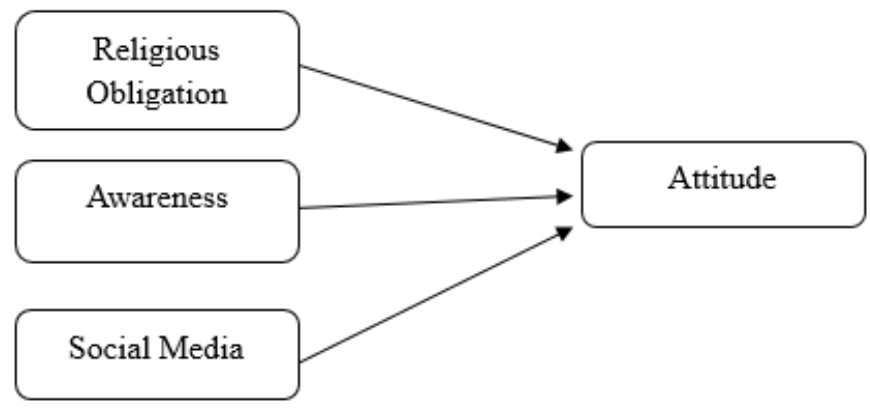

Figure 1: Conceptual framework

\section{Hypotheses:}

H1: Religious Obligation has significant relationship with the attitude toward investing in Islamic mutual funds in the Saudi mutual funds industry.

H2: Awareness has significant relationship with the attitude toward investing in Islamic mutual funds in the Saudi mutual funds industry

H3: Social media has a significant relationship with consumers' attitude toward investing in Islamic mutual funds within the Saudi mutual funds industry.

\section{Research Method:}

In this study, a quantitative research design was employed for both the data collection and analysis. The quantitative primary data were elicited through a survey questionnaire administered on respondents. Data so obtained were subjected to both descriptive and inferential statistical analyses. While the former describes the profile of the respondents, the latter was used to test hypothesized statements. Such an approach allows for establishing and explaining relations between all the variables of interest in this research. Another reason was that the research data were numerical in which case responses to questionnaires administered were used to measure the respondent's perceptions. In addition, quantitative research approach is considered more appropriate when random sampling is used for selecting the sample of the study.

\section{Analysis and Result}

Measurement model:

Partial Least Squares - Structural Equation Modeling (PLS-SEM) was employed to assess the hypothesized model used in the present study. The two models, the measurement and structural models were assessed using Smart PLS3 (Ringle et al., 2004). Using this statistical test, we the measurement model's psychometric properties were assessed, and the structural model's parameters were estimated.

To assess the validity of data for the present research, the analyses employed include: discriminant validity, convergent validity, indicator reliability, and internal consistency reliability. In subsequent sections, the results of the analyses for evaluating the measurement model validity are presented consecutively. 
Table 1: Descriptive and Reliability Statistics

\begin{tabular}{|c|c|c|c|c|}
\hline Latent Constructs & $\begin{array}{l}\text { Questionnaire } \\
\text { Item }\end{array}$ & $\begin{array}{l}\text { Factor } \\
\text { Loadings }\end{array}$ & $\begin{array}{c}\text { Composite / } \\
\text { Construct Reliability } \\
\text { (CR) }\end{array}$ & $\begin{array}{l}\text { Average Variance } \\
\text { Extracted } \\
\text { (AVE) }\end{array}$ \\
\hline \multirow{4}{*}{ Religious obligation } & Q1_1 & 0.718 & 0.890 & 0.672 \\
\hline & Q1_2 & 0.779 & & \\
\hline & Q1_4 & 0.892 & & \\
\hline & Q1_5 & 0.878 & & \\
\hline \multirow{3}{*}{ Awareness } & Q2_1 & 0.762 & 0.851 & 0.656 \\
\hline & Q2_2 & 0.845 & & \\
\hline & Q2_4 & 0.820 & & \\
\hline \multirow{3}{*}{ Social media } & Q3_1 & 0.736 & 0.839 & 0.635 \\
\hline & Q3_3 & 0.823 & & \\
\hline & Q3_5 & 0.829 & & \\
\hline
\end{tabular}

Table 2: AVE Value

\begin{tabular}{|l|l|}
\hline \multicolumn{1}{|c|}{ Constructs } & \multicolumn{1}{c|}{ Average Variance Extracted (AVE) } \\
\hline Religious obligation & $\mathbf{0 . 6 7 2}$ \\
\hline Awareness & $\mathbf{0 . 6 5 6}$ \\
\hline Social Media & $\mathbf{0 . 6 3 5}$ \\
\hline
\end{tabular}

Table 3: Reliability of all Constructs

\begin{tabular}{|c|c|c|}
\hline Latent Constructs & $\begin{array}{c}\text { Composite/ Construct } \\
\text { Reliability (CR) }\end{array}$ & Cronbach Alpha \\
\hline Religious obligation & 0.890 & 0.837 \\
\hline Awareness & 0.851 & 0.738 \\
\hline Social media & 0.839 & 0.723 \\
\hline
\end{tabular}

Both the validity and reliability tests of the hypothesized model in the present study have satisfactory results. Both tests satisfy the assessment criteria for both measurement and structural models. As such, the interpretation of the parameter estimates may be used to test hypothesized statements as well as to draw inferences from the structural model.

\section{Structural model:}

It is vital to validate structural model fit to measure if the data support the hypotheses that the structural model (SM) states (Urbach and Ahlemann, 2010). A successful validation of the evaluation model should precede a structural model analysis. Path coefficients and coefficient of determination $\left(\mathrm{R}^{2}\right)$ are used to measure a structural model. In the present study, the hypothesized correlations among the constructs are determined by four parameters (Henseler et al., 2009).

Table 4: Testing of relationship

\begin{tabular}{|l|l|l|l|l|l|l|l|}
\hline Relationship & StdPh & $\begin{array}{l}\text { Std } \\
\text { Error }\end{array}$ & T-Value & $\begin{array}{l}\mathbf{P} \\
\text { Values }\end{array}$ & $\mathbf{R}^{2}$ & $\mathbf{f}^{2}$ & $\mathbf{Q}^{2}$ \\
\hline Religious obligation -> Attitude & 0.410 & 0.083 & $4.465^{* *}$ & 0.000 & 0.441 & 0.257 & 0.298 \\
\hline Awareness -> Attitude & 0.327 & 0.068 & $3.503^{* *}$ & 0.000 & & 0.077 & \\
\hline Social Media -> Attitude & 0.247 & 0.046 & $5.310^{* *}$ & 0.000 & & 0.094 & \\
\hline
\end{tabular}

Table 5: Hypotheses Result

\begin{tabular}{|l|l|l|l|l|}
\hline Relationship & StdPh & $\begin{array}{l}\text { Std } \\
\text { Error }\end{array}$ & T-Value & $\begin{array}{l}\text { P } \\
\text { Values }\end{array}$ \\
\hline Religious obligation -> Attitude & 0.410 & 0.083 & $4.465^{* *}$ & 0.000 \\
\hline Awareness -> Attitude & 0.327 & 0.068 & $3.503^{* *}$ & 0.000 \\
\hline Social Media -> Attitude & 0.247 & 0.046 & $5.310^{* *}$ & 0.000 \\
\hline
\end{tabular}

The relationship among the variables for this study were tested with six major hypotheses. H1 states that

there is a statistically significant relationship between the religious obligation (RO) and attitude toward investing in IMF in Saudi MF industry. The research findings indicate that hypothesis H1 was supported and religious obligation (RO) and attitude toward have significant relationship on the investing in IMF in Saudi MF industry. Table 4.13 shows Path coefficient $=0.410$, $\mathrm{t}$-value $=4.465$ and $\mathrm{p}$-value $=0.000$, which is $<0.05$.

H2: There is a statistically significant relationship between the awareness (A) and attitude toward investing in IMF in Saudi MF industry. The findings of this study indicate that hypothesis $\mathbf{H 2}$ was supported and had a 
significant relationship between the awareness (A) and attitude toward investing in IMF in Saudi MF industry. Table 4.13 shows Path coefficient $=0.237$, $\mathrm{t}$-value $=3.503$ and $\mathrm{p}$-value $=0.000$, which is $<0.05$.

H3: There is a statistically significant relationship between the social media (SM) and attitude toward investing in IMF in Saudi MF industry. The findings of this study indicate that hypothesis $\mathbf{H 3}$ was supported and had a significant relationship between the social media (SM) and attitude toward investing in IMF in Saudi MF industry. Table 4.13 shows Path coefficient $=0.247$, $\mathrm{t}$-value $=5.310$ and $\mathrm{p}$-value $=0.000$, which is $<0.05$.

\section{Discussion}

The research findings in this study indicate that hypothesis $\mathbf{H 1}$ was supported. The implication of this finding is that the higher the religious obligation of the investors, the higher their attitude towards investing in IMF. In other words, as the investor's basic knowledge in Islamic investing is higher, the higher their attitudinal disposition towads investing in Islamic mutual funds in Saudi Arabia.

The result of this study is consistent with the findings of some previous studies for instance, Abou-Youssef, et. al. (2015); Al Serhan (2016); and Souiden, et. al. (2015). For example, Abou-Youssef, et. Al., (2015) revealed that consumer attitudes toward Islamic banking in Egypt is significantly influenced by religiosity. Similarly, Al Serhan (2016) documented that Religious denomination has a significant influence on boycotting and loyalty behavior of customers. Souiden et al. (2015) revealed that a strong positive relationship exists between an individual's fear for divine punishment and developing favorable attitude towards Islamic Banks.

The research findings also indicate that a statistically significant relationship exists between the awareness (A) of investors and their attitude toward investing in IMF in Saudi MF industry. The possible explanation for this finding could be that where populace lack knowledge about certain thing, they would not appreciate its significance. Hence, there is need for the fund managers to create awareness on the significance of the IMF over the conventional fund. This would help stimulate investor decision toward investing in the fund.

The result of this study is in concord with the findings of previous studies (e.g., Mansor, et al., 2012; Rammal and Zurbruegg 2007; Bley and Kuehn, 2004). Mansor, et al., (2012) shown that there is significant influences of Awareness of Technology, promotion and service quality in the use of e-banking. Rammal and Zurbruegg (2007) awareness is found to influence interest to use Islamic banking. Bley and Kuehn (2004) Awareness concerning Islamic financial products were more Muslim students compared to conventional financial instruments.

The findings indicate significant relationship between the social media (SM) and attitude toward investing in IMF in Saudi MF industry. The possible explanation of this would be that the traditional means of communication and information dissemination are being subsumed by the modern ones reflected in the surge of social media activities. The managers are expected to invest more on the social media such as use of IMF Apps, posting their products and activities on Facebook, having an easy to use and navigate functional website, etc.

The result of this study also aligns with the findings of previous studies (e.g., Boateng and Okoe, 2015; Marsh, 2014; Chu et al., 2013). While Boateng and Okoe (2015) revealed that Consumers' attitude depends on corporate reputation, Marsh (2014) documented that advertisement appearing on a credible website are trusted by consumers. Also, Chu et al (2013) posited that brand consciousness influences users' attitudes towards social media advertising.

\section{Conclusion}

The objective set out by this research at the beginning was to examine factors that are likely to influence Saudi investors' attitudes towards IMF investments. The findings of the study showed that all the three factors identified by the research have a statistically significant effect on the attitudes of Saudi investors towards IMF investments. These findings have a number of implications. On the practical side, the findings of the research offer better awareness about factors that affect IMF existing and potential investors. IMF Managers can use these findings to know aspects they need to improve in order to attract more Saudi investors. On the theoretical side, the findings extend the frontier of knowledge in the use of TPB by adopting variables such as RO, A, SM in the MF industry in general and particularly in the Saudi economic context. This is expected to fill a gap within the extant literature since there are no earlier studies that previously investigated this area with similar sets of variables within the context of Saudi MF industry.

\section{References}

Abedifar, P., Ebrahim, S. M., Molyneux, P., \&Tarazi, A. (2015). Islamic banking and finance: Recent empirical literature and directions for future research. Journal of Economic Surveys, 29(4), 637-670.

Abou-Youssef, M. M. H., Kortam, W., Abou-Aish, E., \& El-Bassiouny, N. (2015). Effects of religiosity on consumer attitudes toward Islamic banking inEgypt. International Journal of Bank Marketing, 33(6), 786-807

Adeyemi, B.K., Huud, S. \&Shuriye, A.O. (2013). Impacts of new media technology on Muslim-western relation. Journal of Asian Scientific Research, 3(12), 1210 - 1219.

Ahmad, N and Haron S (2002). "Perceptions of Malaysian Corporate Customers Towards Islamic Banking Products and Services." International Journal of Islamic Financial Services 3(4). 
Al Serhan, O. (2016). The impact of religiously motivated boycotts on brand loyalty among transnational consumers (Doctoral dissertation, Cardiff Metropolitan University).

Al-Hyari, K., Alnsour, M., Al-Weshah, G., \&Haffar, M. (2012). Religious beliefs and consumer behaviour: from loyalty to boycotts. Journal of Islamic Marketing, 3(2), 155-174.

Amin, H., Rahim Abdul Rahman, A., LaisonSondoh Jr, S., \& Magdalene Chooi Hwa, A. (2011). Determinants of customers' intention to use Islamic personal financing: The case of Malaysian Islamic banks. Journal of Islamic Accounting and Business Research, 2(1), 22-42.

Aminuddin Mat Jusoh (1999). A Study on Secondary School Students Awareness Towards the Management, Mara University of Technology.

Armstrong, G. and Kotler, P. (2004), Marketing: An Introduction, Prentice-Hall, Upper Saddle River,NJ.

Ashraf, D. (2013). Performance evaluation of Islamic mutual funds relative to conventional funds: Empirical evidence from Saudi Arabia. International Journal of Islamic and Middle Eastern Finance and Management, 6(2), 105-121.

Assael H. (1995). Consumer Behaviour and Marketing Action. 5th Ed. USA: International Thompson Publishing,

Barakat, A., Jabali, M.A.A. \&Nazmy, E. (2011). Constraints affecting the efficiency of mutual funds in the Saudi financial market. International Research Journal of Finance and Economics, 81, 38 - 49.

Bernheim, B. D., Garrett, D. M., \& Maki, D. M. (2001). Education and saving: The long-term effects of high school financial curriculum mandates.Journal of Public Economics, 80(3), 435-465.

Berthon, P., Pitt, L., \& Campbell, C. (2008). Ad lib: When customers create the ad. California management review, 50(4), 6-30.

Bley, J. \& Kuehn, K. (2004). Conventional versus Islamic finance: Student knowledge and perception in the United Arab Emirates. International Journal of Islamic Financial Services, 5(4).

Boateng, H., \&Okoe, A. F. (2015). Consumers' attitude towards social media advertising and their behavioural response: The moderating role of corporate reputation. Journal of Research in Interactive Marketing, 9(4), 299-312.

Chalmers, J., \& Reuter, J. (2010). What is the impact of financial advisors on retirement portfolio choices \& outcomes? (No. orrc10-05). National Bureau of Economic Research.

Chu, S.C., Kamal, S. and Kim, Y. (2013), “Understanding consumers' responses toward social media advertising and purchase intention toward luxury products", Journal of Global Fashion Marketing, Vol. 4 No. 3, pp. 158174.

Chu, S.C., Kamal, S. and Kim, Y. (2013), “Understanding consumers' responses toward social media advertising and purchase intention toward luxury products", Journal of Global Fashion Marketing, Vol. 4 No. 3, pp. 158174.

Deighton, J., and Kornfeld, L. (2009). Interactivity's unanticipated consequences for marketers and marketing. Journal of Interactive Marketing, 23(1), 4-10.

Dewri, L. V., and Islam, M. R. (2016). Performance of Public Mutual Funds (PMFs) in Emerging Economies: A Case of Bangladesh. International Journal of Business and Management, 11(6), 296.

Erol, C. and El-Bdour, R. (1989). Attitudes, behaviour and patronage factors of bank customers towards Islamic banks. International Journal of Bank Marketing,7(6), 31-3.

Erol, C., Kaynak, E. \& El-Bdour, R. (1990). Conventional and Islamic banks: Patronage behaviour of Jordanian customers.International Journal of Bank Marketing, 8(4), 25-35.

Essoo, N., and Dibb, S. (2004). Religious influences on shopping behaviour: An exploratory study. Journal of Marketing Management, 20(7-8), 683-712.

Gallagher, Katherine, K. Dale Foster, and Jeffrey Parsons (2001), "The Medium Is Not the Message: Advertising Effectiveness and Content Evaluation in Print and on the Web,' Journal of Advertising Research, 41 (4), 57 70.

Goldsmith, R.E. and Lafferty, B.A. (1999), “Corporate credibility's in consumers' attitudes and purchaseintentionswhenahighvsalowcredibilityendorserisusedinthead",Journalof Business Research, Vol. 44 No. 2, pp. 109-116.

Hamid, A. and Nordin, N. (2001). A study on Islamic banking education and strategy for the new millennium: Malaysian experience. International Journal of Islamic Financial Services, 2(4).

Henseler, J., Ringle, C. M., \&Sinkovics, R. R. (2009). The use of partial least squares path modeling in international marketing. In New challenges to international marketing (pp. 277-319). Emerald Group Publishing Limited.

Hill, P.C. and Pargament, K.I. (2003), “Advances in the conceptualization and measurement of religion and spirituality: implications for physical and mental health research", American Psychologist, Vol. 58, pp. 664-74.

Hirschman, E. C. (1983). Religious affiliation and consumption processes: An initial paradigm. Research in marketing, 6, 131-170. 
Internet World Stats. 2016. World Internet Users Statistics Usage and World Population Stats. http://www.internetworldstats.com/stats.htm.

Koenig, H.G., McCullough, M. and Larson, D.B. (2000), Handbook of Religion and Health, Oxford University Press, New York, NY.

Kotler, P., Armstrong G. (2004). Principle of Marketing. USA: Prentice Hall.

Li, C., \&Bernoff, J. (2011). Groundswell: Winning in a world transformed by social technologies. Harvard Business Press.

Li, H., Edwards, S.M. and Lee, J.H. (2002), "Forced exposure and psychological reactance: antecedents and consequences of the perceived intrusiveness of pop-up ads", Journal of Advertising,Vol.31 No.3,pp.83-95.

Mangold, W. G., \&Faulds, D. J. (2009). Social media: The new hybrid element of the promotion mix. Business horizons, 52(4), 357-365.

Mansor, F., \&Bhatti, M. I. (2011). The Islamic mutual fund performance: New evidence on market timing and stock selectivity. In International Conference on Economics and Finance Research IPEDR, 2011 (Vol. 4).

Mansor, N., Shariff, A., \&Manap, N. R. A. (2012). Determinants of awareness on Islamic financial institution ebanking among Malaysian SMEs. International Journal of Business and Social Science, 3(5).

Marsh, P. (2014), 5 things to know about content, advertising and trust, available at: www. newscyclesolutions.com/5-things-to-know-about-content-advertising-and-trust/ (accessed 11March2015).

Metawa, S. and Almossawi, M. (1998). Banking behaviour of Islamic bank customers: Perspectives and implications." International Journal of Bank Marketing, 16(7), 299-315.

Mitchell, A.A. and Olson, J.C. (1981), "Are product attributes the only mediator of advertising effects on brand attitude?", Journal of Marketing Research, Vol. 18 No. 3, pp. 318-332.

Mulhern, F. (2009), "Integrated marketing communications: from media channels to digital connectivity", Journal of Marketing Communications, Vol. 15 Nos 2/3, pp. 85-101

Rammal, H. \&Zurbruegg, R. (2007). Awareness of Islamic banking products among Muslims: The case of Australia. Journal of Financial Services Marketing, 12(1), 65-74.

Rammal, H. \&Zurbruegg, R. (2007). Awareness of Islamic banking products among Muslims: The case of Australia. Journal of Financial Services Marketing, 12(1), 65-74.

Ringle, C., Wende, S., \& Will, A. (2004). SmartPLS 2.0.M3 [Retrieved from http://www.smartpls.de

SAIFR (2015). Saudi Arabia Islamic finance Report Retrieved from file://C:/Users/dell/Desktop/12022\%/REFERNSES/Saudi\%20Arabia\%20-\%20Islamic\%20Finance\%20Re port\%20November\%202015.pdf

Saunders, M. L., \& Lewis, P. (2009). P. \& Thornhill, A.(2009). Research methods for business students, 4.

Sharon G. (1999). Small Bank Try to Capitalize on the Consumer Anxiety. Las Vegas: Business Press.

Shimp (1997). Advertising, Promotion and Supplemental aspects of International Marketing communication. 4th Ed. USA: Prentice Hall Inc.

Souiden, N. and Rani, M. (2015) 'Consumer attitudes and purchase intentions toward Islamic banks: The influence of religiosity', International Journal of Bank Marketing, 33(2), pp. 143-161. doi: 10.1108/ijbm-10-20130115 .

Urbach, N., \& Ahlemann, F. (2010). Structural equation modeling in information systems research using Partial Least Square. Journal of Information Technology Theory and Application 11(2), 5-40.

Waldfogel, J. (2009). Lost on the web: Does web distribution stimulate or depress television viewing?. Information Economics and Policy, 21(2), 158-168.

Walters, C. G., Bergiel, B. J. (1989). Consumer behavior: A decision-making approach. South-Western Pub

Wang, Y., \& Sun, S. (2010). Examining the role of beliefs and attitudes in online advertising: A comparison between the USA and Romania. International Marketing Review, 27(1), 87-107.

Wiebe, K. F., \& Fleck, J. R. (1980). Personality correlates of intrinsic, extrinsic, and nonreligious orientations. The Journal of Psychology, 105(2), 181-187.

Zeng, F., Huang, L. and Dou, W. (2009), "Social factors in user perceptions and responses to advertising in online social networking communities", Journal of Interactive Advertising, Vol.10No.1,pp.1-13. 